\title{
PERLINDUNGAN HUKUM BAGI KONSUMEN TERHADAP PENGGUNA KOSMETIK YANG TIDAK TERDAFTAR BADAN PENGAWASAN OBAT DAN MKANAN (BPOM) (Studi Penelitian Di Kota Idi Kabupaten Aceh Timur)
}

\author{
${ }^{1}$ Ayu Humaira, ${ }^{2}$ Yulia, ${ }^{2}$ Fatahillah \\ Co. Author : fatahillah@unimal.ac.id \\ ${ }^{1}$ Fakultas Hukum, Universitas Malikussaleh \\ ${ }^{2}$ Dosen Fakultas Hukum Universitas Malikussaleh
}

\begin{abstract}
Abstrak/Intisari
Perlindungan hukum merupakan hal yang sangat penting bagi konsumen. Pemerintah telah memberikan perlindungan hukum bagi konsumen yang diatur dalam Pasal 4 Undang-Undang Nomor 8 Tahun 1999 Tentang Perlindungan Konsumen. Konsumen kosmetik di Kota Idi sangat banyak memakai produk kosmetik yang tidak terdaftar BPOM, akibatnya kerusakan kulit timbul setelah pemakaian dilakukan oleh konsumen. Masyarakat Kota Idi selaku konsumen kosmetik mudah tergiur dengan efek dari cream yang dapat memutihkan kulit dalam jangka waktu yang singkat dan masyakat tidak memiliki kesadaran terhadap hak perlindungan hukum yang mereka dimiliki. Penelitian ini bertujuan untuk mengetahui dan menjelaskan perlindungan hukum terhadap konsumen yang menggunakan kosmetik yang tidak terdaftar di BPOM, untuk mengetahui dan menjelaskan hambatan BBPOM Banda Aceh dalam perlindungan hukum terhadap konsumen pengguna kosmetik yang tidak terdaftar di BPOM dan upaya IBBPOM Banda Aceh dalam penyelesaian hambatan terhadap konsumen pengguna kosmetik yang tidak terdaftar di BPOM. Penelitian ini menggunakan metode kualitatif dengan pendekatan yuridis empiris. Data diperoleh melalui penelitian kepustakaan (library research) dan didukung dengan penelitian lapangan (field research). Analisis data dilakukan secara deskriptif (descriptive analysis). Berdasarkan hasil penelitian diketahui bahwa pelaksanaan perlindungan hukum terhadap konsumen belum terlaksana maksimal. Hambatan dalam perlindungan konsumen yaitu kurangnya pengetahuan konsumen dan pelaku usaha tentang peraturan terkait kosmetika. Upaya yang dilakukan yaitu strategi pencegahan (sosialisasi dengan masyarakat), strategi pengawasan dan strategi penindakan. Disarankan kepada masyarakat lebih bijak dalam memilih produk kosmetik. Kesadaran hukum bagi pelaku usaha dalam memproduksi kosmetik yang tidak legal dan menjalankan kewajiban selaku pelaku usaha sesuai peraturan perundangundangan dan BPOM lebih meningjatkan peredaram kosmetik dipasaran.
\end{abstract}

Kata Kunci: Perlindungan Hukum, Konsumen, Kosmetik. 


\section{PENDAHULUAN}

Kosmetik adalah paduan bahan yang siap untuk digunakan pada bagian luar badan (epidermis, rambut, kuku, bibir, dan organ kelamin bagian luar), gigi, dan rongga mulut untuk membersihkan, menambah daya tarik, mengubah penampakan, melindungi supaya tetap dalam keadaan baik, memperbaiki bau badan tetapi tidak dimaksudkan untuk mengobati atau menyembuhkan suatu penyakit. Kosmetik merupakan bagian dari kebutuhan hidup manusia yang sudah ada dan semakin berkembang dari masa ke masa.

Penggolongan kosmetik menurut kegunaannya dibagi menjadi kosmetik perawatan kulit (skin care cosmetic) dan kosmetik riasan (make-up). Kosmetik perawatan kulit yaitu untuk perawatan kulit yang diperlukan untuk merawat kebersihan dan kesehatan kulit, Kosmetik riasan ada prinsipnya lebih menitik beratkan fungsinya untuk mempercantik dan merias, produk kosmetik riasan tidak lengkap tanpa pengetahuan mengenai pentingnya pewarna sebagai komponen primer. Seiring dengan perkembangan zaman, dalam kehidupan masyarakat modern, terutama kaum wanita mempunyai keinginan untuk tampil cantik, maka dari itu tidak diherankan lagi banyak wanita rela menghabiskan uangnya untuk membeli kosmetik.

Perdagangan bebas yang didukung oleh kemajuan teknologi telekomunikasi dan informatika telah memperluas ruang gerak arus transaksi barang dan/atau jasa melintasi batas-batas wilayah suatu negara, sehingga barang dan/atau jasa yang ditawarkan bervariasi baik produksi luar negeri maupun produksi dalam negeri. Kondisi yang demikian pada satu pihak mempunyai manfaat bagi konsumen karena kebutuhan konsumen akan barang dan/atau jasa yang diinginkan dapat terpenuhi serta semakin terbuka lebar kebebasan untuk memilih aneka jenis dan kualitas barang dan/atau jasa sesuai dengan keinginan dan kemampuan konsumen.

Keinginan wanita untuk selalu tampil cantik banyak dimanfaatkan oleh pelaku usaha dengan memproduksi kosmetik yang tidak memenuhi persyaratan dan diedarkan dengan harga murah, kebanyakan wanita tertarik untuk membeli kosmetik dengan harga yang murah serta memiliki reaksi yang cepat terhadap wajah, tanpa memikirkan kandungan dan kelayakan dari produk tersebut, bahkan banyak wanita memilih jalan alternatif untuk membeli produk walaupun produk kosmetik yang di beli tidak memenuhi persyaratan serta tidak terdaftar di Badan Pengawas Obat dan Makanan (BPOM).

Kosmetik yang dijual dengan harga murah, kebanyakan tidak adanya izin BPOM, sehingga tidak layak disebut suatu produk kosmetik, karena tidak mencantumkan kandungan bahan baku yang terdapat dalam kosmetik, tidak adanya petunjuk pakai dari kosmetik tersebut, bahkan banyak kosmetik yang beredar dipasaran tanpa adanya merek dan waktu kadaluarsa.

Konsumsi masyarakat terhadap produk kosmetik cenderung terus meningkat, seiring dengan perubahan gaya hidup masyarakat termasuk pola konsumsinya. Sementara itu pengetahuan masyarakat masih belum dapat memilih dan menggunakan produk secara tepat, benar dan aman. Di lain pihak iklan tentang kosmetik di promosi secara gencar mendorong agar konsumen tertarik membelinya. Hal tersebut memungkinkan beredar luasnya kosmetikkosmetik dalam memenuhi kebutuhan pasar yang menjadi ladang bisnis untuk pelaku usaha, 
baik kosmetik yang memiliki izin edar dari pemerintah sampai yang tidak berizin edar dari pemerintah. Kegiatan seperti ini seringkali dijadikan lahan bisnis bagi pelaku usaha yang mempunyai iktikad buruk akibat posisi konsumen yang lemah karena tidak adanya perlindungan yang seimbang untuk melindungi hak-hak dari konsumen.

Banyak kosmetik yang beredar di Kota Idi pada tahun 2018 tidak terdaftar pada BPOM, seperti kosmetik merek Temulawak Two Way Cake, Collagen, Tabita, Cream HN, masker Naturgo, Cream BB Chusion Bio Aqua. Akibat pelaku usaha yang menjual kosmetik tanpa adanya izin edar dari BPOM. Konsumen yang mengalami kerugian akibat efek samping dari pemakaian kosmetik diatas, kejadian tersebut dialami oleh seorang mahasiswi bernama Irnasari, pemakaian paket pertama cream wajah Tabita tidak memberi efek apapun pada wajahnya, tetapi ketika Irnasari memakai untuk paket kedua, wajah Irnasari muncul flek-flek hitam di daerah pipi dan kantong mata. Selanjutnya Khalisa, mengatakan setelah pulang berlibur ke sebuah pulau di Indonesia, kulitnya nampak kusam, dia tertarik membeli hand body pemutih yang kemasannya hanya botol putih polos tanpa ada merek, komposisi dan anjuran pakai, beberapa minggu pemakaian mulai terlihat perubahan, kulitnya nampak lebih putih dan bersih, setelah 2 (dua) bulan pemakaian hand body whitening tersebut kulit khalisa mulai muncul bintik merah dan muncul garis-garis seperti stretch marks. Konsumen yang mengeluh karena terjadinya iritasi, muncul jerawat, dan rasa terbakar pada kulit seperti kasus diatas telah mengalamai peristiwa yang menyebabkan mereka tidak aman dan tidak selamat. BPOM telah mengelurakan Public Warning dengan tujuan agar masyarakat tidak menggunakan kosmetik berbahaya tersebut, karena dapat menyebabkan kerugian konsumen yang memakainya.

Berdasarkan Pasal 4 Undang-Undang Nomor 8 Tahun 1999 tentang Perlindungan Konsumen (UUPK), Bab III, Bagian Pertama, hak konsumen adalah sebagai berikut:

a. Hak atas kenyamanan, keamanan dan keselamatan dalam mengkonsumsi barang dan/atau jasa;

b. Hak untuk memilih barang dan/atau jasa serta mendapatkan barang dan/atau jasa tersebut sesuai dengan nilai tukar dan kondisi serta jaminan yang dijanjikan;

c. Hak atas informasi yang benar, jelas dan jujur mengenai kondisi dan jaminan barang dan/atau jasa;

d. Hak untuk didengar pendapat dan keluhannya atas barang dan/atau jasa yang digunakan;

e. Hak untuk mendapatkan advokasi perlindungan konsumen secara patut;

f. Hak untuk mendapatkan pembinaan dan pendidikan konsumen;

g. Hak untuk diperlakukan atau dilayani secara benar dan jujur serta tidak diskriminatif;

h. Hak untuk mendapatkan kompensasi, ganti rugi dan/atau penggantian, apabila barang dan/atau jasa yang diterima tidak sesuai dengan perjanjian atau tidak sebagaimana mestinya;

i. Hak-hak yang diatur dalam peraturan perundang-undangan lainnya.

Berdasarkan Pasal 5 UUPK, BabIII Bagian Pertama, kewajiban konsumen adalah sebagai berikut:

a. Membaca atau mengikuti petunjuk informasi dan prosedur pemakaian atau pemanfaatan barang dan/atau jasa, demi keamanan dan keselamatan; 
b. Beritikad baik dalam melakukan transaksi pembelian barang dan/atau jasa;

c. Membayar sesuai dengan nilai tukar yang disepakati;

d. Mengikuti upaya penyelesaian hukum sengketa perlindungan konsumen secara patut.

Hal-hal yang diatur dalam Pasal 6 UUPK tentang hak pelaku usaha adalah sebagai berikut:

a. Hak untuk menerima pembayaran yang sesuai dengan kesepakatan mengenai kondisi dan nilai tukar barang dan/atau jasa yang diperdagangkan;

b. Hak untuk mendapat perlindungan hukum dari tindakan konsumen yang beritikad tidak baik;

c. Hak untuk melakukan pembelaan diri sepatutnya di dalam penyelesaian hukum sengketa konsumen;

d. Hak untuk rehabilitasi nama baik apabila terbukti secara hukum bahwa kerugian konsumen tidak diakibatkan oleh barang dan/atau jasa yang diperdagangkan;

e. Hak-hak yang diatur dalam ketentuan peraturan perundang-undangan lainnya.

Sementara berdasarkan Pasal 7 UUPK, kewajiban pelaku usaha adalah sebagai berikut,

a. Beritikad baik dalam melakukan kegiatan usahanya;

b. Memberikan informasi yang benar, jelas dan jujur mengenai kondisi dan jaminan barang dan/atau jasa serta memberi penjelasan penggunaan, perbaikan dan pemeliharaan;

c. Memperlakukan atau melayani konsumen secara benar dan jujur serta tidak diskriminatif;

d. Menjamin mutu barang dan/atau jasa yang diproduksi dan/atau diperdagangkan berdasarkan ketentuan standar mutu barang dan/atau jasa yang berlaku;

e. Memberi kesempatan kepada konsumen untuk menguji, dan/atau mencoba barang dan/atau jasa tertentu serta memberi jaminan dan/atau garansi atas barang yang dibuat dan/atau yang diperdagangkan;

f. Memberi kompensasi, ganti rugi dan/atau penggantian atas kerugian akibat penggunaan, pemakaian dan pemanfaatan barang dan/atau jasa yang diperdagangkan;

g. Memberi kompensasi, ganti rugi dan/atau penggantian apabila barang dan/atau jasa yang diterima atau dimanfaatkan tidak sesuai dengan perjanjian.

Berdasarkan uraian dan alasan tersebut diatas, penulis tertarik untuk melakukan penelitian dan akan menuliskannya dalam sebuah karya ilmiah yang berbentuk skripsi dengan judul : Perlindungan Hukum Bagi Konsumen Terhadap Pengguna Kosmetik Yang Tidak Terdaftar Di Badan Pengawas Obat Dan Makanan (BPOM) (Studi Penelitian di Kota Idi Kabupaten Aceh Timur)

\section{METODE PENELITIAN}

Studi penelitian ini menggunakan jenis penelitian kualitatif, penelitian kualitatif adalah suatu cara analisis hasil penelitian terjun langsung kelapangan yang menghasilkan data deskriptif, yaitu data yang dinyatakan oleh responden secara tertulis atau lisan serta juga tingkah laku yang nyata, yang diteliti dan dipelajari sebagai sesuatu yang utuh. Dengan demikian, pendekatan kualitatif yang menghasilkan data deskriptif ini bersifat 
menggambarkan/menguraikan sesuatu hal sesuai apa adanya dari tulisan atau ungkapan dan tingkah laku yang dapat diobservasi.

Adapun pendekatan penelitian ini menggunakan pendekatan yuridis empiris, yaitu prosedur penelitian yang dilakukan dengan menemukan teori-teori mengenai proses sebenarnya berkerjanya hukum dalam lingkungan hidup masyarakat, selain dilakukan melalui studi kepustakaan atau library research, penelitian ini juga dilakukan dengan bertatap muka secara langsung dengan responden maupun informan dalam melakukan penelitian lapangan.

Analisa data yang digunakan dalam penelitian ini adalah analisis kualitatif yaitu teknik analisa data yang menjelaskan data yang diperoleh dari penelitian lapangan (hasil wawancara) maupun kepustakaan yang dianalisis kedalam uraian-uraian sehingga ada akhirnya dapat menjawab permasalahan yang ada.

\section{PEMBAHASAN}

\section{A. PELAKSANAAN PERLINDUNGAN HUKUM TERHADAP KONSUMEN PENGGUNA KOSMETIK YANG TIDAK TERDAFTAR BPOM}

Perlindungan hukum merupakan upaya penting untuk menjamin adanya kepastian hukum yang melindungi konsumen, karena kedudukan konsumen lebih cenderung menjadi sasaran itikad buruk dari pelaku usaha. Dengan adanya perlindungan hukum bagi konsumen diharapkan dapat terhindar dari praktik-praktik yang merugikan konsumen. Pelaksanaan perlindungan hukum bagi konsumen dikota Idi bahwa kosumen di lindungi oleh hukum namun masyarakat yang menggunakan kosmetik yang tidak terdaftar BPOM tidak melaporkan kepada pemerintah ketika kosmetik tersebut tidak terdaftar BPOM dan memberikan efek merusak kulit bagi konsumen sehingga perlindungan hukum bagi konsumen terhambat karena upaya kerjasama dengan masyarakat tidak terlaksana. Lembaga Swadaya Masyarakat Pejuang Hak Konsumen memberikan upaya pencegahan melalui kegiatan komunikasi dan edukasi kepada masyarakat di kota Idi ketika memakai produk yang tidak terdaftar BPOM tidak melapor kepada pidak pemerintaha banwa mereka telah tertipu dari produsen yang nakal.

Berdasarkan peraturan perundang-undangan diatas bahwa pelaksanaan perlindungan hukum di Kota Idi sesuai dengan peraturan undang-undang diatas namun kesadaran masyarakat dan pengetahuan akan perlindungan hukum adalah hak meraka. Masyarakat tidak tahu dan tidak paham akan perlindungan hukum tersebut selaku produsen atau penjual juga kurang pengetahuan mengenai aturan hukum. Seharusnya pembuatan kosmetik harus diperhatikan pula mengenai wadah kosmetik dan penandaan kosmetik. Pengaturan mengenai

wadah kosmetik ini bertujuan untuk keamananpemakai kosmetik. Wadah dan pembungkus kosmetik ini kemudian diberikan penandaan yang berisikan informasi yang lengkap, objektif, dan tidak menyesatkan. Di Kota Idi kebutuhan akan kosmetika oleh masyarakat yang semakin meningkat dari waktu ke waktu menyebabkan produsen dan pelaku usahaberusaha untuk memenuhi kebutuhan tersebut dengan memproduksi dan mejualkan berbagai macam bentuk, fungsi dan manfaat kosmetika kepada masyarakat. Namun agar tercipta kegiatan bisnis kosmetika yang aman dan baik bagi pihak konsumen dan pelaku usaha maka diperlukanlah peraturan perundang-undangan yang mengatur hal tersebut. 
Pelaksanaan perlindungan hukum terhadap konsumen yang menggunakan produk kosmetik tidak terdaftar pada BPOM dapat dilakukan dengan tiga cara yaitu:

1. Pencabutan izin edar kosmetik dan izin industri kosmetik,

2. Penarikan produk kosmetik yang mengandung zat-zat berbahaya dari peredaran (sanksi administratif),

3. Penerapan sanksi dan ganti rugi,

4. Perlindungan hukum dari aspek hukum pidana.

Cara lain untuk melindungi hak;hak konsumen yang diatur dalam pasal 19 angka 1 tentang tanggung jawab pelaku usaha. UUPK menyertakan tanggung jawab pelaku usaha yang berkaitan dengan produk barang yang dihasilkan oleh pelaku usaha sebagaimana dinyatakan dalam pasal 7 sampai 11 UUPK, tanggung jawab produk mengacu pada tanggung jawab produsen. Dasar gugatan untuk tanggung jawab produk dapat dilakukan atas landasan adanya pelanggaran jaminan, kelalaian dan tanggung jawab mutlak pengguna kosmetik yang mengandung zat-zat berbahaya yang dilakukan oleh konsumen, pelaku usaha dapat dikenakan sanksi apabila unsur kesalahan dapat dibuktikan, dimana beban pembuktian ada pada pihak yang tergugat. Sanksi yang dijatuhkan pada pelaku usaha berupa sanksi administratif dan sanksi pidana.

Berdasarkan hasil penelitian terhadap konsumen kosmetik yang tidak terdaftar BPOM yaitu Khalisa, seorang ibu rumah tangga mengatakan ia tergiur untuk menggunakan cream pemuth yang digunakan oleh temannya. Awal mula pemakaian ia merasa banyak terdapat perubahan daripemakaian kosmetik tersebut seperti hilangnya jerawat, bintik-bintik pada wajah dan wajahnya juga terlihat lebih putih selama pemakaian kosmetik tersebut. Selain harganya murah kosmetik tersebut mudah didapatkan dipasaran dan hasilnya mudah terlihat. Namun setelah pemakaian 3 (tiga) bulan, wajah Khalisa terasa gatal dan memerah, awalnya ia mengira karena alergi terhadap makanan, ia pun tetap melanjutkan pemakaian produk kosmetik tersebut. Setelah seminggu pemakaian kosmetik setelah muka Khalisa mengalami gatal dan memerah lalu timbul bintik-bintik kecil pada muka Khalisa, ia mengaku ternyata penyebab dari mukanya gatal dan memerah lalu timbul bintik-bintik adalah kosmetik yang selama ini ia gunakan.

Selanjutnya Irnasari, seorang pengguna kosmetik di Kota Idi mengatakan pada saat itu wajah Irnasari sangat kusam lalu ia memutuskan membeli cream putih lewat online, dalam beberapa minggu wajah Irnasari sudah banyak terlihat perubahan. Dia menggunakan cream tersebut selama 4 (empat) bulan, setelah berhenti menggunakan cream tersebut tibatiba wajah Irnasari tumbuh banyak sekali jerawat.

Berdasarkan hasil penelitian lapangan atas konsumen pengguna produk kosmetik yang tidak terdaftar BPOM diatas dapat disimpulkan bahwa konsumen tidak melakukan komplain karna mereka tidak mengetahui atas produk yang merugikan mereka dapat melaporkan kerugian mereka kepada pemerintah untuk mendapatkan ganti rugi atas kesalahan pelaku usaha.

\section{B. Hambatan BBPOM Banda Aceh Terhadap Perlindungan Hukum Bagi Konsumen Pengguna Kosmetik Yang Tidak Terdaftar}


UUPK tidak berjalan seperti yang diharapkan, banyaknya konsumen meresa dirugikan akibat dari produk kosmetik yang tidak terdaftar BPOM, Di era modern ini, untuk terlihat sempurna sangat mudah, dengan menggunakan kosmetik dapat membuat mereka terlihat lebih cantik, bersih, dan wangi, meskipun terdapat kosmetik yang mengandung bahan berbahaya namun konsumen tidak pernah takut akan hal itu karena mereka menggangap kosmetik tersebut dapat mengubah segalanya dalam waktu yang sangat singkat. Berdasarkan hasil penelitian yang dilakukan hambatan dalam memberikan perlindungan terhadap konsumen yang mengalami kerugian akibat kosmetik yang tidak terdaftar di Kota Idi disebabkan beberapa faktor penyebab antara lain:

\section{Faktor Ekonomi}

Faktor ekonomi atau motivasi pelaku usaha dalam memalsukan kosmetik untuk mendapatkan keuntungan yang sebanyak-banyaknya sebab kosmetik asli biasanya harganya jauh lebih mahal, sedangkan pemakai kosmetik menginginkan harga yang murah yang disesuaikan dengan kemampuan ekonomi mereka. Mahalnya syarat untuk pendaftaran sesuai dengan pasal 2 angka 2 menyebutkan "kosmetik yang dapat dimasukkan kedalam wilayah Indonesia untuk diedarkan adalah kosmetik yang telah memiliki izin edar. Dengan adanya aturan bahwa produk kosmetik yang diedarkan harus memiliki izin edar, mengharuskan pelaku usaha untuk mendaftarkan produk kosmetik yang akan diedarkan. Menurut ibu Endang faktor beredarnya kosmetik tidak terdaftar BPOM adalah biaya pendaftaran untuk mendapatkan label BPOM tergolong mahal. Sehingga pelaku usaha tidak melakukan pendaftaran produk kosmetik karena biaya pendaftaran lebih mahal jika dibandingkan dengan keuntungan saat mengedarkan produk kosmetik. Namun, hasil dari wawancara dengan ibu Endang, beliau mengatakan biaya pendaftaran produk kosmetik sebesar Rp.500.000 (Lima Ratus Rupiah) berupa Penerimaan Negara Bukan Pajak (PNBP). Beliau mengatakan yang membuat mahal pada saat pendaftaran bukan biaya pendaftaran, namun persyaratan untuk mendapatkan izin produksi yang diatur pada Peraturan Menteri Republik Indonesia Nomor 1175/MENKES/PER/VII/2010.

\section{Faktor tingginya permintaan pasar}

Faktor penyebab terjadinya peredaran kosmetik tidak terdaftar BPOM selanjutnya adalahpermintaan masyarakat yang tinggi maka beredar kosmetik-kosmetik tidak terdaftar BPOM dipasarkan dan digunakan oleh masyarakat banyak. Permintaan masyarakat yang tinggi salah satu faktor utama penyebab terjadinya peredaran kosmetik yang tidak terdaftar BPOM. Produsen juga memanfaatkan pasar untuk menjual kosmetik tidak terdaftar BPOM . jika tidak ada permintaan pasar yang tinggi untuk dapat menggunakan kosmetik tersebut, maka pelaku usaha juga tidak akan mengedarkan kosmetik tersebut dikarenakan tidak adanya permintaan pasar untuk mengkonsumsi kosmetik tidak terdaftar BPOM. kosmetik tidak terdaftar BPOM sudah banyak tersebar dipasaran, karena meningkatnya permintaan pasar sehingga produsen pun mengikuti keinginan pasar.

\section{Faktor kurangnya pengetahuan masyarakat}

Salah satu faktor peredaran kosmetik adalah kurangnya pengetahuan masyarakat untuk membedakan kosmetik asli dengan palsu membuat peredaran barang ini marak terjadi, umumnya masyarakat hanya tertarik pada harga yang murah. 


\section{Faktor kurang tegasnya sanksi}

Salah satu faktor beredarnya kosmetik adalah sanksi terhadap pelaku usaha yang memproduksi atau menjual kosmetik tidak membuat efek jera. Sebab sanksi yang dilaksanakan hanya berupa penyitaan. Bellum ada sanksi yang lebih berat seperti:

a. Pencabutan izin usaha

b. Belum adanya pelaku di pidana atau membayar ganti rugi

\section{Faktor kurangnya pengawasan}

Kurangnya pengawasan yang dilakukan oleh BPOM Propinsi juga dikarenakan pihak BPOM hanya mengawasi penjual dari produk kosmetik saja. Sedangkan penjual kosmetik mendapatkan produk kosmetik tersebut dari distributor tidak resmi. Pihak BPOM juga harus dapat mengawasi distributor tersebut karena jika tidak ada distributor tersebut maka penjual juga tidak menjual produk kosmetik tidak terdaftar BPOM dan juga pihak yan memproduksi kormetik tersebut.

\section{Upaya Penyelesaian Hambatan Dalam Pelaksanaan Perlindungan Terhadap Konsumen Pengguna Kosmetik Yang Tidak Terdaftar BPOM}

Kesadaran hukum dan kepatuhan hukum, juga peran serta masyarakat terhadap upaya perlindungan konsumen, sedangkandalam UUPK Pasal 29 ayat 1 dinyatakan bahwa "Pemerintah bertanggung jawab atas pembinaan penyelenggaraan perlindungan konsumen yang menjamin diperolehnya hak konsumen dan pelaku usaha serta dilaksakannya kewajiban konsumen dan pelaku usaha". Upaya pemerintah dalam melindungi pengguna kosmetik yang tidak terdaftar BPOM adalah melalui pemberdayaan masyarakat/konsumen, pengawasan dan penegakan sanksi. Upaya yang dilakukan BBPOM Banda Aceh dalam melindungi konsumen yaitu:

\section{Peran Pemerintah dan Penegak Hukum (Strategi Pencegahan)}

Pemberdayaan masyarakat melibatkan tiga pilar/sub sistem, ketiga sub sistem tersebut yaitu pemerintah, produsen dan konsumen/masyarakat. Masing-masing sub sistem tersebut perlu dilakukan peningkatan pengetahuan serta pemberdayaan. Kepada insitusi pemerintah dilakukan melalui berbagai pelatihan. Kepada produsen dan konsumen diberikan pengetahuan berbagai aspek tentangproduk kosmetik. Oleh karena itu BBPOM Banda Aceh telah melaksanakan beberapa program pemberdayaan masyarakat/produsen seperti di bentuknya Unit Layanan Pengaduan Konsumen (ULPK) serta dilakukan Komunikasi Informasi Edukasi (KIE), penyebaran informasi, sosialisasi, mengenalkan slogan CEK KLIK (cek Kemasan, cek Label, cek Izin Edar dan cek Kadaluwarsa), membentuk duta cilik BPOM ditingkat SD, SMP, SMA, penyebaran informasi dalam bentuk penyuluhan langsung, pameran, kegiatan melalui media elektronik seperti dialog di televisi local dan radio, serta melalui media social Facebook dan Instagram (sosialisasi melalui media elektronik dan sosialisasi dengan masyarakat dengan terjun langsung kelapangan).

2. Strategi Pengawasan

BBPOM melakukan pengawasan ke sarana produksi dan distribusi obat dan makanan termasuk didalamnya sarana kosmetik, pengawasan iklandan penandaan, sampling dan pengujian, dan memperkuat koordinasi dengan lintas sector lain. Dalam upaya melakukan 
pengawasan terhadap produk kosmetik yang tidak terdaftar BPOM, yang menjadi sasaran untuk pengawasan kosmetik yaitu:

a. Terjun langsung ke lapangan atau tempat yang diduga banyak menjual

kosmetika seperti supermarket, minimarket, toko kosmetik, dan salon

kecantikan;

b. Membuka dan meneliti kemasan kosmetika;

c. Melihat kemasan apakah kosmetik tersebut memenuhi syarat atau tidak.

Lembaga Perlindungan Swadaya Masyarakat menurut pasal 44 ayat (2) UUPK Nomor 8 Tahun 1999, memiliki kesempatan untuk berperan aktif dalam mewujudkan perlindungan konsumen. upaya preventif pihaknya melakukan sosialisasi kepada konsumen, yaitu memberi informasi terkait produk kosmetik yang diedarkan harus terdaftar BPOM. Sosialisasi tersebut biasanya dilakukan secara tidak resmi, yaitu memberi informasi kepada pihak terdekat seperti keluarga, saudara, teman dan lain-lain. Sosialisasi tersebut bertujuan untuk meningkatkan kesadaran masyarakat untuk berhati-hati dalam hal memilih produk kosmetik. Kegiatan sosialisasi dilakukan agar konsumen melaporkan bila ada peredaran kosmetik yang tidak terdaftar BPOM.

3. Strategi Penindakan

Melakukan kegiatan intelijen dan patrol siber untuk penjualan online, melakukan pemetaan rawan kasus, melakukan operasi penindakan (skala provinsi, nasional, maupun internasional) serta melakukan proses penyidikan tindak pidana dibidang obat dan makanan. Untuk penjual online yang menjual kosmetik yang tidak memiliki izin edar atau mengandung bahan berbahya dapat diambil langkah pemblokiran akun melalui Kementerian Kominfo. Dalam melakukan upaya untuk mencegah beredarnya kosmetik yang tidak terdaftar BPOM secara terus-menerus melakukan pengawasan. Pengawasan yang menjadi sasaran untuk pengawasan kosmetik, BBPOM masuk di supermarket, minimarket, toko kosmetik,pasar swalayan dan salon kecantikan.

Pada saat BBPOM turun kelapangan melakukan pemantauan dan pengawasan, jika ada pelaku usaha yang menjual kosmetik tanpa izin edar atau mengandung bahan berbahaya, BBPOM akan memberikan pembinaan langsung kepada pelaku usaha untuk tidak lagi menjual kosmetik tidak terdaftar ataupun mengandung bahan berbahaya, apabila pelaku usaha masih menjual kosmetik tanpa izin edar, maka BBPOM akan memberikan sanksi admisnistratif sesuai pelanggaran yang dilakukan. jika terdapat kosmetik beredar tidak memenuhi ketentuan maka BBPOM Propinsi melaporkan ke BPOM karena menurut tidak hanya di Propinsi tertentu saja yang mendapatkan kosmetik tidak memenuhi ketentuan. Jika ada BBPOM lain menemukan juga kosmetik yangsama maka BPOM memerintahkan untuk menarik barang dan BPOM mengeluarkan public warning. Setelah kosmetik tersebut masuk di daftar publicwarning BPOM terus memantau kelapangan. Jika konsumen tersebut masih beredar di pasaran maka produk kosmetik akan dimusnahkan.

\section{KESIMPULAN}

1. Perlindungan hukum terhadap produk kosmetik yang tidak terdaftar pada BPOM di Kota Idi belum terlaksana maksimal, masih banyak pemakai kosmetik Kota Idi tidak 
mengetahui adanya peraturan perundang-undangan yang mengatur tentang perlindungan konsumen.

2. Hambatan yang ditemui dalam peredaran kosmerika yang tidak teraftar pada BPOM disebebkan kurangnya pengetahuan konsumen tentang bahaya produk kosmetik tanpa BPOM, kurangnya pengetahuan pelaku usaha tentang peraturan terkait kosmetika dan kurangnya kepatuhan pelaku usaha untuk melaksanakan pembinaan dari petugas BBPOM.

3. Upaya BBPOM dalam penyelesaian terhadap konsumen pengguna kosmetik yang tidak terdaftar BPOM, pemerintah dalam melindungi konsumen penggguna kosmetik yang tidak terdaftar BPOM yaitu melakukan strategi pencegahan (sosialisasi dengan masyarakat dengan media elektronik maupun terjun kelapangan), strategi pengawasan dan strategi penindakan.

\section{DAFTAR PUSTAKA}

Ahmadi Miru dan Sutarman Yodo, Hukum Perlindungan Konsumen, Raja Grafindo Persada, Jakarta, 2010.

Ahmadi Miru \& Sutarman Yodo, Hukum Perlindungan Konsumen, PT Raja Grafindo Persada, Jakarta, 2004.

Az Nasution, Hukum Perlindungan Konsumen Suatu Pengantar, Jakarta: Diadit Media, Jakarta, 2002

Bambang Sunggono, Metode Penelitian Hukum, Raja Grafindo Persada, Jakarta, 2006.

Erman Rajagukguk, Hukum Perlindungan Konsumen, Bandung, Mandar Maju, 2010.

Mukti Fajar ND dan Yulianto Achmad, Dualisme Penelitian Hukum Normatif dan Empiris, Pustaka Pelajar, Yogyakarta, 2010

Shidarta, Hukum Perlindungan Konsumen Indonesia, Gramedia Widiasarana Indonesia, Jakarta ,2006.

Tim Penyusun, Panduan Penulisan Tugas Akhir Skripsi, Fakultas Hukum Universitas Malikussaleh, 2016.

Firjat Anggraini, Sulwan Pusadan, Rosnani Lakunna, Jurnal, Fungsi Dan Peranan Badan Pengawasan Obat Dan Makanan (Bpom) Dalam Perlindungan Konsumen Terhadap Makanan Yang Mengandung Zat Berbahaya, http://jurnal.untad.ac.id/jurnal/index.php/LO/article/download/10425/8218diakses tanggal 20 Januari 2020

Sekar Ayu Amiluhur Priaji, Perlindungan Hukum Terhadap Peredaran Kosmetik Yang Merugikan Konsumen, skripsi, fakultas hukum, universitas islam Indonesia Yogyakarta, 2018, hlm 108.

Ginda Tera Geza, Penegakan Sanksi Pidana Bagi Pelaku Usaha Produksi Kosmetik Ilegal Yang Mencantumkan Nomor Izin Edar Palsu Bpom Di Kota Palembang, Skripsi, Fakultas Hukum, Universitas Sriwijaya, Palembang, 2018 Hlm 42

Cahaya Setia Nuarida Triana,2015, Skripsi tentang Perlindungan Hukum Bagi Konsumen Terhadap Peredaran Kosmetik Yang Mengandung Bahan Berbahaya Di Kabupaten Banyumas.

http://fh.unsoed.ac.id/sites/default/files/bibliofile/SKRIPSI 3.pdf. 